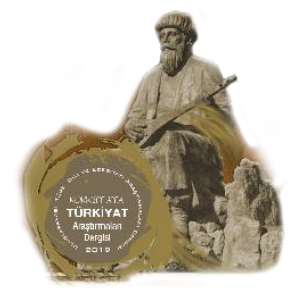

KORKUT ATA TÜRKIYYAT ARAŞTIRMALARI DERGİSI

Uluslararası Türk Dili ve Edebiyatı Araştırmaları Dergisi

The Journal of International Turkish Language $\mathcal{E}$

Literature Research

| Sayı/Issue 5 (Ağustos/August 2021), s. 195-206

Geliş Tarihi-Received: 29.07.2021

Kabul Tarihi-Accepted: 26.08.2021

Araştırma Makalesi-Research Article

ISSN: $2687-5675$

DOI: $10.51531 /$ korkutataturkiyat.976332

\title{
Halk ve Divan Edebiyatı Müşterekliği Bağlamında Karacaoğlan Şiirlerinde ve Bâkî Divanı'nda Kumru Kuşu
}

\author{
Dove Bird in Karacaoğlan Poems and Bâkî's Divan in the Context of the \\ Commonality of Folk and Divan Literature
}

Yasin UYSAL

Öz

\begin{abstract}
Sözlü ve yazılı kültür ürünleri insana, yaşama, doğaya ve canlılara ait sayısız unsuru içerisinde barındırır. Türk edebiyatının vazgeçilmez iki kolu olan halk ve divan şiiri de insana, doğaya, yaşama ve canlılara ait pek çok özelliği ve öğeyi içerir. Sanılanın aksine, aralarında yoğun bir biçim, konu ve hayal müştereklikleri bulunduran divan ve halk şairleri doğayı ve canlıları şiirlerinde farklı açılardan işlemişlerdir. Her iki gelenek içerisinde yetişen şairler farklı tarzlarda şiirler yazmış olsalar da Türk kültürü içerisinde yer alan veya daha sonradan eklenen unsurları ele almışlardır. Bu bakımdan halk ve divan şiirin konu, kaynak ve yer yer hayal benzerliği bulunmaktadır. Söz konusu bu benzerlikleri veya müştereklikleri incelemek, Türk edebiyatı araştırmalarına katkı sağlayacaktır. Yapılan bu çalışma içerisinde de halk edebiyatının ünlü ozanlarından olan Karacaoğlan'ın şiirlerinde ve divan edebiyatının temsilcilerden olan Bâkî́nin Divan'ında yer alan kumru kuşu hakkında bir inceleme ortaya konmuştur. Yapılan bu inceleme, divan ve halk edebiyatı müşterekliği bakımından ele alınmıştır. Çalışmada ilk olarak divan ve halk edebiyatı müşterekliklerine değinilmiştir. Ardından da kumru/üveyik kuşu hakkında çeşitli bilgiler verilip Karacaoğlan ve Bâkî şiirlerinde söz konusu bu kuşun yer aldığı dörtlükler ve beyitler incelenmiştir. İncelemelerin sonunda Karacaoğlan'ın ve Bâkî'nin şiirlerinde kumru kuşunun nasıl ele alındığına dair bir sonuca ulaşılmaya çalışılmıştır.
\end{abstract}

Anahtar Kelimeler: Halk edebiyatı, divan edebiyatı, Karacaoğlan, Bâkî, kumru.

\begin{abstract}
Oral and written culture products contain countless elements of human, life, nature and living things. Folk and divan poetry, which are two indispensable branches of Turkish literature, also contain many characteristics and elements belonging to human beings, nature, life and living things. Contrary to popular belief, divan and folk poets, which have intense commonalities of form, subject and imagination, treated nature and living things from different angles in their poems. Although the poets who grew up in both traditions wrote poems in different styles, they dealt with the elements in Turkish culture or added later. In this respect, folk and divan poetry have similarity in subject, source and place to place. Examining these similarities or commonalities will contribute to Turkish literature research. In this study, a study about the dove bird in the poems of Karacaoğlan, one of the famous poets of folk literature, and in the Divan of Bâki, who is one of the representatives of divan
\end{abstract}

* Tezli Yüksek Lisans Öğrencisi, Marmara Üniversitesi, Türkiyat Araştırmaları Enstitüsü, Türk Dili ve Edebiyatı Ana Bilim Dalı, Türk Halk Edebiyatı Bilim Dalı, İstanbul/Türkiye, e-posta: yasin.uysal@marun.edu.tr, ORCID: https://orcid.org./0000-0002-0189-6414. 
literature, was put forward. This analysis has been handled in terms of the commonality of divan and folk literature. Firstly, the commonness of divan and folk literature was mentioned in the study. Then, various information about the dove / turtledove bird was given, and the quatrains and couplets in which this bird appeared in the poems of Karacaoğlan and Bâkî were examined. At the end of the investigations, it was tried to reach a conclusion about how the dove bird is handled in the poems of Karacaoğlan and Bâkî.

Keywords: Folk literature, divan literature, Karacaoğlan, Bâkî, dove.

\section{Giriş}

Edebiyat ve edebî ürünler oluştukları sosyal yapı, coğrafya, dil, din ve kültürün pek çok özelliğini içerisinde barındırır. Bu açıdan edebiyat ve edebî ürünler ele alınan bu unsurların birer yansımasıdır. Toplumların sosyo-bilişsel özellikleri edebiyat tarzlarını ve ürünlerini şekillendirmektedir. Bu yüzden belirli bir topluma ait olan edebiyat ve edebi ürünler o toplumun içerisindeki insanlar tarafından anlaşılır ve yayılır. Türk edebiyatı da Türk toplumun anladığı, ürettiği ve yaşattığı bir sanat geleneği ve kültürüdür.

Pek çok toplumsal gelişme ve değişmeden dolayı Türk edebiyatı kendi içerisinde belirli dönemlere ve tarzlara (üslûp, sanat ve akım) ayırılmıştır. Divan ve halk edebiyatı da Türk edebiyatının tarihî süreç içerisinde birbirlerinden farklı estetik unsurları ve sanatları benimseyen iki şubesidir. Bu iki kol her ne kadar farklı estetik kaideleri ve sanatları benimsemiş olsa da köken ve kaynak olarak aynı kültürü, yaşamı, düşünceyi ve inancı ele almaktadır. Hem divan hem de halk edebiyatı Türk kültürü ve edebiyatının iki yapı taşıdır. İçeriklerinde benzer konu, motif ve mazmunlara yer vermektedirler. İki tarz arasındaki farkları bazı dil hususlarında ve bahsedilen konu, motif ve mazmunların ele alınış biçimlerinde görmekteyiz. Ancak her iki alan da aynı kültür, gelenek, dil ve tarihe dayanmaktadır. Günümüzde çoğunlukla bu iki edebiyat arasındaki farklılık ve zıtlıklara dikkat çekilse de iki tarz arasındaki müştereklikler ve benzerlikler farklarından ve zıtlıklarından daha fazladır. Bundan dolayı divan ve halk edebiyatı araştırmaları, müştereklikleri konu edinen çalışmalara ihtiyaç duymaktadır.

Türk edebiyatı kapsamında ve Anadolu sahasında oluşup gelişen halk ve divan edebiyatı, birbirlerinden çeşitli açlardan etkilenmişlerdir. Divan edebiyatı halk edebiyatından biçimsel (şarkı ve tuyug) ve içerik olarak etkilenmiştir. Aynı şekilde halk edebiyatı da divan edebiyatından biçimsel (divanî, selis, semai, kalenderî, satranç...) ve içerik bakımından etkilenmiştir. Bunların dışında bu iki edebiyat kültürü Türk halkına ait unsurları, özellikleri, duyguları ve düşünceleri yansıtmaktadır. Âşık ve sevgili arasındaki ilişki, güzellik-sevk-sefa, İslam inancı, Türk-İslam kültürü, savaşlar, halk inanc1-hekimliğiastrolojisi, tarihi olaylar- kişiler vb. konular her iki edebiyatta sıklıkla, benzer veya farklı şekillerde ele alınmıştır. Uçan hayvanlar sınıfında yer alan kuş türleri de hem divan hem de halk edebiyatında çeşitli motif, mazmun ve benzetmeler ile ele alınan konulardandır. Kuşların ele alınış biçimleri iki tarzda da benzer yönlere sahiptir. Bu çalışmanın ana konusu oluşturan kumru veya üveyik kuşu halk ve divan şiirinde yer alan müşterekliklerdendir. Türk halkının gördüğü, duyduğu ve bildiği bu kuşun divan ve halk edebiyatında kullanılması, her ne kadar farklı şubelere veya kollara ayrılsa da Türk edebiyatının bir bütün olarak aynı köke dayandığını göstermektedir.

Bu çalışma ile birlikte ünlü halk ozanlarından Karacaoğlan'ın şiirlerinde ve divan edebiyatının temsilcilerinden Bâkî'nin Divan'ında kumru/üveyik kuşunun kullanımını tespit ederek divan ve halk edebiyatının müşterekliklerine dikkat çekmek istenmektedir. Çalışmada ilk olarak divan ve halk edebiyatı müştereklikleri hakkında bazı açıklamalar yapılacaktır. Müşterekliklerden sonra kumru kuşu hakkında çeşitli bilgiler verilecek olup ardından Karacaoğlan şiirlerinde ve Bâkî Divanı' nda kumru kuşunun yer aldığı dörtlükler ve beyitler incelenecektir. İncelemenin ardından müştereklik bağlamında bir sonuca

Korkut Ata Türkiyat Araştırmaları Dergisi
Uluslararası Türk Dili ve Edebiyatı Araştırmaları Dergisi
The Journal of International Turkish Language E Literature Research
Sayı 5/ Ağustos 2021


ulaşılmaya çalışılacaktır.

\section{Halk ve Divan Edebiyatı Müştereklikleri Hakkında}

Aynı köke ve kültüre dayanan Türk edebiyatı kendi içerisinde farklı kollara ayrılsa da bu kollar arasındaki benzerlikler ve müştereklikler her daim mevcuttur. Günümüze kadar Türk edebiyatının klasik edebiyat ve halk edebiyatı kolları arasındaki farklılıklara dikkat çekilmiştir. Ancak bu iki edebiyat arasındaki benzerlikler ve müştereklikler daha fazladır.

Halk şiiri ile divan şiiri arasında gerek dil ve şekil gerek muhteva bakımından muhtelif farklar bulunmakla beraber neticede, aynı milletin malı olarak bunların temelinde zevk, duygu, heyecan ve fikirde birlik ve benzerliğin mevcudiyeti, tabii olduğu kadar zaruridir de. Divan şiirini, klişe ifade ve ortak mefhumların bolluğu ve devamlılığı ile tenkid edenler, benzerlerini ve ortak ifade kalıplarını fazlasıyla halk şiirinde de bulacaktır. Aslında bu husus, şiirimizin bütünlügüüü gösterdiği kadar müşterek bir kültürün, kendini her zümreye kabul ettirdiği, cemiyet olarak da bir vahdeti yansıttığ1 inancındayız (Çelebioğlu 1998: 711).

Türk edebiyatının ele alınan bu iki edebiyat tarzı bazı dil ve içerik uyuşmazlığından dolayı zıt iki kutup olarak görülmüştür. Hem bazı divan şairlerinin halk şairlerini (ozan/âşık) küçümsemesi hem de bazı halk şairlerinin divan şiirini ve şairini "yabancı" olarak görmesi divan ve halk edebiyatının iki ayrı edebiyat olarak değerlendirilmesine neden olmuştur. Ancak 16. yüzyıldan sonra hem halk şairlerinin divan edebiyatını anlaması ve öğrenmesinden hem de divan şairlerinin şiirlerinde halka ait daha çok unsura yer vermesinden dolayı halk ve divan edebiyatı birbirine yakınlaşmış ve iki tarz edebiyat arasındaki benzerlikler gün yüzüne çıkmaya başlamıştır. Bu çalışmanın ana konusunu da divan ve halk edebiyatı arasındaki benzerlikler oluşturmaktadır.

Halk edebiyatı ve divan edebiyatı birbirinden farklı estetik özellikler ve sanatlar dâhilinde oluşturulmuş edebiyat türüdür. Ancak her iki edebiyat da Türk kültürü, yaşamı, inancı ve düşüncesi merkezli olarak ürünler ortaya koymuştur. Aralarında birçok ortak özellik bulunmasına rağmen bu ortak özelliklere dikkat edilmeyip aralarındaki farklara odaklanılmaktadır. Bu farklara odaklanmak iki edebiyat kültürü arasındaki müşterekliği zaman zaman yok saymaya neden olmaktadır. Farklara bakacak olursak hem divan hem de halk edebiyatındaki pek çok tarzı ve metodu farklı bir tür ve şekil olarak çıkarmak gerekebilir. Örnek olarak mesnevîler divan edebiyatı hâricinde başlı başına bir tarz olabilir. Aynı şekilde halk edebiyatında yer alan tekke-tasavvuf edebiyatı da başlı başına bir inceleme alanı olabilir. Bu açıdan müşterekliklere bakmanın farklılıklara bakmaktan daha yararlı olacağını söyleyebiliriz.

Divan edebiyatı ve halk edebiyatı Türk edebiyatının ve kültürünün iki yapı taşıdır. Her ne kadar farklılıkları ile dikkat çekseler de bu iki edebiyat birbirini tamamlamaktadır. Konu, içerik ve amaç için aynı motifler ve aynı mazmunlar kullanılan bu iki edebiyatta farklılık sadece bazı dil hususlarında ve ele alış biçimlerindedir. Halk edebiyatının içinde biraz divan edebiyatı vardır. Aynı şekilde, divan edebiyatının içinde de biraz halk edebiyatı vardır. Bu açıdan bir "yin" ve "yang" olan bu iki edebiyat bir "Tai Ji" sembolü gibidir.

Divan şiiri hakkında günümüze kadar sayısız çalışma yapılmıştır ve ileriki yıllarda da yapılacaktır. Halk edebiyatı alanı ve şiiri hakkında da pek çok araştırma yapılmıştır. Ancak bu çalıma ve araştırmalar büyük bir oranda alan temelli yapılmıştır. Divan ve halk edebiyatı arasındaki müşterekliği konu alan çok az çalışma yapılmıştır. Divan ve halk 
edebiyatı arasındaki ilişkiye ilk olarak M. Fuad Köprülü değinmiştir. Bu konu ile ilgili olarak Köprülü'nün, “Klâsik edebiyat üzerinde halk edebiyatımızın ve halk edebiyatı üzerinde klâsik edebiyatımızın bir takım tesir ve aksi tesirleri göze çarpmamak mümkün değil" (1980: 117-18) şeklindeki sözleri önemlidir. Karşılaştırmalı bir inceleme ile her iki edebiyattaki ortak özellikler gün yüzüne çıkabilir. Köprülü'nün dışında Mehmet Çavuşoğlu da Divan Şiiri adlı bir yazısında halk edebiyatındaki divan şiiri etkilerine dikkat çekmiştir.

18. ve 19. yüzyıllardan günümüze kalan cönklerde, okuma-yazma bilen hak kesiminden kişilerin derledikleri defterlerde, özellikle 16. yüzyılda Bâkî, Fuzûlî, Yahya Bey, Hayretî gibi ünlü divan şairlerinin şiirlerine rastlamamız, divan şiirinin sadece yüksek aydın kesiminde okunmakla kalmadığını ispat ediyor (Çavuşoğlu 1986: 8). Halk, beğendiği ve kendine yakın bulduğu şairleri ve şiirleri sosyal hayatlarının, inançlarının ve edebiyatlarının yer aldığı çeşitli cönk ve benzeri defterlere eklemiştir. Divan şiirine ait şairlerin ve şiirlerin halk defterlerinde yer alması halkın divan edebiyatına yakın olduğunun göstergesidir.

Köprülü ve Çavuşoğlu'nun yanı sıra Âmil Çelebioğlu divan ve halk edebiyatı arasındaki müşterekliğe en çok dikkat çeken isim olmuştur. Çelebioğlu, Eski Türk Edebiyatı Araştırmaları ve Türk Edebiyatı'nda Mesnevi gibi çalışmalarında halk edebiyatı ve divan edebiyatı arasındaki benzerlikleri ve ortaklıkları ele alıp incelemiştir. Âmil Çelebioğlu, Türk Edebiyatı'nda Mesnevi adlı çalışmasında divan edebiyatının ve halk edebiyatının ortak bir ürünü olan "halk tipi mesnevi"leri inceleyerek bu iki edebiyatın müşterekliğini bilimsel bir şekilde inceler. Çelebioğlu'nun şu sözleri, divan ve halk edebiyatı bütünlüğüne vurgu yapmaktadır:

\section{Halk, Divan, Tekke \\ Duvar, kemer, kubbe}

Çelebioğlu'na göre nasıl ki bir binada duvar, kemer ve kubbe birbirine bağlı olup ayrı düşünülemezlerse, Türk Edebiyatı çatısı altında da Halk, Divan ve Tekke edebiyatlarını birbirinden ayrı düşünmek mümkün değildir (Çelebioğlu 1998: 1).

Divan edebiyatında ve halk edebiyatında söz konusu benzerlikler sadece sosyal yapı, coğrafya, kültür ve inançsal ortaklıktan kaynaklanmamaktadır. Bu iki tarz arasında zaman zaman konu, şekil, tür ve dil aktarımları ve etkileşimleri de gerçekleşmiştir. Bunun nedeni bazen divan şairinin halk şiirine bazen de halk şairinin divan şiirine yakınlaşmasıdır. Halk edebiyatı içerisinde divan şiirine en yakın tarz âşık şiiridir. Saz şairleri, divan şiirine benzer bir yapı ile bir gelenek oluşturup yaşattıkları için sanat ve estetik özellikleri göz önünde bulundurmuşlardır. Bu açıdan divan şairlerinin şiirlerinden etkilenmişlerdir.

Divan şiirini en çok kullanan şairler ise Erzurumlu Emrah, Bayburtlu Zihnî, Develelî, Seyranî, Tokatlı Nurî, Ispartalı Seyranî, Beşiktaşlı Gedâ̂, Narmanlı Sümmanî, Celâlî, Remzi, Âşık Ruşenî, Dertli, Pinhanî, Lütfî, Cezmî, Kemalî, Geredeli Figanî, Teslim Abdal (tekke şairi), Âşık Velî ve Kul Halil gibi şahıslardır (Yağbasan 1992: 26).

Âşık şiiri içerisindeki saz şairleri divan şairlerinin şiirlerinden hareketle aruz ölçüsünün bazı kalıpları ile gazel, murabba, muhammes, müseddes ve müstezat şekillerinde şiirler yazmaya çalışmışlardır. Bu uyarlama çalışmalarından hareketle oluşturdukları şiirlere divan/divanî, selis, semâi, kalenderî, satranç ve vezn-i âher gibi adlar koymuşlardır. Saz şairleri bu gibi şiirlerde hem hece hem de aruz ölçüsünü kullanmaya çalışmışlardır. Bu tür şiirleri içeren toplu eserlerde hem dörtlük hem de beyit biçimleri yer almaktadır. Saz şairleri divan şiirinden çeşitli şekil ve biçimlerde etkilendikleri gibi konu ve içerik bakımından da etkilenmişlerdir. Her ne kadar iki tarz da

Korkut Ata Türkiyat Araştırmaları Dergisi
Uluslararası Türk Dili ve Edebiyatı Araştırmaları Dergisi
The Journal of International Turkish Language \& Literature Research
Sayı 5/ Ağustos 2021


Türk kültürü ve geleneği içinde şekillense de divan şiiri kaynakları ve konuları çok farklı şekillerde ele alıp yansıtmıştır. Bu farklı yaklaşımdan âşık tarzı şiir de etkilenmiştir. Ancak bu etkilenme daha çok taklit aşamasında kalmıştır. Saz şairi, divan şiirindeki tasavvuf, inanç, mazmun-motif, efsane-mit ve söz sanatlarından oldukça fazla etkilenmiştir.

Türk edebiyatı ve kültürünün vazgeçilmez bir parçası olan divan edebiyatı başlangıçta Türk halk kültürüne bağlıydı. Kaşgarlı Mahmut, Karamanoğlu Mehmet Bey ve Ali Şir Nevâi gibi isimler eserlerini Türkçe yazmışlar ve Türkçeyi savunmuşlardır. Divan şiiri zaman geçtikçe dini ve siyasi bazı nedenlerden dolayı Arap ve Fars dillerinin etkisi altında kalarak Türk halk kültüründen ve geleneğinden uzaklaşmaya başlamıştır. Her ne kadar bir uzaklaşma söz konusu olsa da kökeni yine Türk edebiyatıdır. Ahmet Fakih, Şeyyad Hamza, Kadı Burhaneddin, Taşlıcalı Yahya ve Fuzûlî gibi divan şairleri, bütün şiirlerinde olmasa bile bazı şiirlerinde halk şiirine ait unsur ve yapıları kullanmışlardır.

İslam öncesinde ve halk şiirinde nazım birimi dörtlüktür. İslami dönem ile birlikte Arap ve Fars edebiyatının etkisi ile divan şiirine beyitler hâkim olmuştur. Ancak halk şiirinin etkisi ile birlikte divan şiirinde murabba, terbi, şarkı, rubaî ve tuyug gibi dörtlüklerle oluşan nazım biçimleri ortaya çıkmıştır. 16. yüzyıldan itibaren pek çok divan şairi, Türk edebiyatı geleneğinin ve âşık tarzı şiirin etkisiyle hece vezni ve dörtlüklerle şiirler yazmıştır. Zaifî, Âşık Çelebi, III. Murat, Nedim, İzzet Molla, Âkif Paşa ve Münif Paşa gibi pek divan şairi hece veznini kullanmıştır.

Tekke ve tasavvuf şiiri ile yakın bir ilişkisi olan divan şiiri, halk şiiri ile olan münasebetini tekke ve tasavvuf şiiri ile sağlamıştır. 16. yüzyıldan itibaren saz şairlerinin ve âşık tarzı şiirin Anadolu'da yaygınlaşmasıyla ile divan şairlerinin halk şiirine ilk başlardaki olumsuz bakışı değişmeye başlamıştır. Ayrıca IV. Murat ile IV. Mehmet'in bazı şiirlerinde hece ölçüsünü kullanması divan şairlerinin halk şiirine olan ilgilerini artırmıştır. 17. yüzyıla gelindiğinde Âşık Ömer ve Gevherî́nin ünü bütün Anadolu'yu etkilediği gibi divan şairlerini de etkilemiştir.

Klasik şairlerimizin şiirlerinde atasözü, deyim ve halk ağzına yakın söyleyişlere çokça rastlanmaktadır. Şimdiye kadar lâyıkıyla dikkat edilmeyen bu husus, divan şairinin halk kültürü ile nasıl alâkalı olduğunu gösteren bir delildir (Kurnaz 2011: 53). Divan şairi ve şiiri köken itibari ile Türk toplumuna ait olduğu için divan şiirinde atasözleri ve deyimlerin yer alması çok normaldir. Türkçeye, sade dile ve halk şiirine ilk yöneliş Türkî-i Basit hareketi ile olmuştur. 15. yüzyılda Aydınlı Visâlî ile başlayan bu hareket 16. ve 17. yüzyıllarda yaygınlık kazanmıştır. 17. yüzyılda Nâ'ilî-i Kadîm ve Neşâtî şiirlerinde sade bir dil kullanmışlardır. Ayrıca şiirlerinde atasözleri ve deyimlere yer vermişlerdir. 17. yüzyılda divan edebiyatı içerisinde gerçekleşen Mahallileşme hareketi ile divan şiiri yüzünü halk diline ve şiirine çevirmiştir. Başta Nedim olmak üzere pek çok yetkin divan şairi şiirlerinde sade bir dil kullanmaya başlayıp halk şiirinden çeşitli unsurları benimsemeye başlamışlardır. Halk dili, kültürü, gelenekleri, inanışları, anlatıları, yaşam tarzı ve şiiri artık divan şiirinde gözle görülür bir şekilde yer almaya başlamıştır. Divan şiirinin kalıplaşmış biçimleri, manzumları ve dili yavaş yavaş değişmiştir.

\section{Müştereklik Bağlamında Karacaoğlan Şiirlerinde ve Bâkî Divanı'nda Kumru}

Toplumların kültürlerinde ve inançlarında yer alan gerçek veya hayalî kuşlar sözlü ve yazılı edebiyat ürünlerinde sıklıkla sembol, motif ve benzetme aracı olarak kullanılmaktadır. Bunun yanı sıra sosyolojik açıdan, gerçek ve hayalî kuşların toplum kültüründe ve edebiyatında yer alması gelişmiş bir medeniyetin izlerini yansıtır. Türk edebiyatı içerisinde yer alan halk ve divan şiirinde de kuş motifi ve mazmunları karşımıza

Korkut Ata Türkiyat Araştırmaları Dergisi
Uluslararası Türk Dili ve Edebiyatı Araştırmaları Dergisi
The Journal of International Turkish Language E Literature Research
Sayı 5/ Ağustos 2021


sıklıkla çıkmaktadır. Bülbül, papağan, karga, şahin/doğan, anka, hüma, tavus, güvercin, keklik vb. kuşlar divan ve halk edebiyatında renk, ötüş, uçuş, sekiş gibi özellikleri ve sevgili-âşık-rakip benzetmeleri ile sıkça kullanılmıştır. Hem divan hem de halk şiirinde en çok adı geçen, benzetme ve manzum öğesi olarak kullanılan kuş bülbüldür. Anka, simurg, hüma ve hüdhüd kuşları ise iki tarzda da hayalî kuşlar olarak karşımıza çıkar. Ayrıca her iki şiir sanatında sevgili bazen avcı bazen de güzel bir kuş olarak yer almaktadır. Âşık ise feryat eden kuşlara benzetilmektedir.

Bu çalışmanın ana konusunu oluşturan kumru veya üveyik kuşu da divan ve halk edebiyatında müşterek bir şekilde yer alan kuşlardandır. Üveyik kuşu ornitolojiye ${ }^{1}$ göre kumru kuşunun bir alt türüdür. Bundan dolayı çalışma içerisinde kumru ve üveyik aynı kuş olarak değerlendirilecektir.

\subsection{Kumru}

Kumru TDK Sözlüğ̈̈̈ne göre köken olarak Farsça “kumrî” kelimesine dayanmaktadır ve "güvercinler takımında, güvercinden küçük, boz, gri renkli bir kuş (Streptopelia)" şeklinde tanımlanmaktadır. TDK Sözlüğ̈̈'nde kumru köken olarak Farsça olarak değerlendirilse de Ferit Devellioğlu'na göre kumrî (2006: 527) kelimesi Arapça kökenlidir ve yine kumru anlamina gelen kamârî (2006: 485) kelimesinden türemiştir.

Kumru kuşunun boyu yaklaşık 28 ve $33 \mathrm{~cm}$ arasındadır. Kül veya bej renklere sahip olan kumrunun boyun bölgesinde siyah çizgiler ya da halkalar bulunmaktadır. Kumrular genel olarak kırsalda, bahçelerde, ormanlarda, köylerde, kasabalarda ve şehirlerde yaşamaktadırlar. Yuvalarını çalılara, ağaç dallarına, telefon-elektrik direklerine ve çatı kenarlarına yapmaktadırlar. Göçer kuşlar arasında yer alan kumrular tek eşli bir şekilde yaşamaktadırlar ve ortalama bir yıl ömürleri bulunmaktadır. Buğday, arpa, yulaf, ay çekirdeği, üzüm gibi taneli yapıdaki besinleri ve böcek türlerini tüketmektedirler.

Kumrular, halk arasında guguk ve üveyik/üveyk olarak da bilinmektedir. Bazı durumlarda kumru ve üveyik farklı kuşlar olarak incelenmiştir. Ancak üveyik, kumrunun bir alt türüdür ve çok benzer kuşlardır. Üveyiğe fâhte de denmektedir. Farsça olan fâhte, üveyik kuşu demektir (Devellioğlu 2006: 248). Bir güvercin türü olan üveyiğe yabani güvercin de denilir (Onay 1992: 162). Kuş, genel olarak kızılımsı pas rengindedir. Sırt ve kanat örtü tüyleri koyu kahverengidir. Karın ve kuyruk altı tüyleri beyazdır. Kuyruk tüyleri koyu gridir. Kuyruk tüylerinin orta tüyler dışında kalanlarının uçları beyazdır. Gaga koyu gri, bacaklar kirli kırmızıdır. Göz portakal rengindedir. Boyu $28 \mathrm{~cm}$ olan üveyik ürkek bir kuştur (Eskigün 2006: 80).

Kumrunun sesiyle zararlı haşerâtı uzaklaştırdığına inanılır. Eşlerine sadakatleriyle meşhurdurlar. İnanışa göre eşlerden herhangi biri ölecek olsa geride kalan kumru artık hayatı boyunca bir başka kumru ile eşleşmez. Ömrü hep feryat ile geçer (Ceylan 2007: 172). Bu özelliği ile divan şiirinde sıklıkla yer almaktadır. Kumru kuşu halk edebiyatında genel olarak ötüşü, uçuşu ve görünüşü bakımından şiirlerde yer almıştır. Bazen dağ yamaçların bazen de dağın etrafında uçan kumrular halk şiirinde güzel sevgilileri simgelemiştir. Ötüşü bakımında divan şiirinde bülbül ile benzer özelliklere sahiptir. Bülbül ve kumru sabah erken saatlerde ötmeye başlar. Bülbül gülüne seslenirken kumru da servisine seslenir. Ayrıca bülbül ve kumru baharın müjdeleyicisi olarak kabul edilir. Her ikisi de canlanmayı ve tazeliği temsil eder.

Üveyik (kumru) daima sık yapraklı, yüksek ağaçlara, servi bulamazsa söğüt ve kavaklara konar. Avcılardan, yırtıcı kuşlardan kendini muhafaza için serve konduğu şüphesizdir. Servinin bulunduğu yerde yılan da bulunması, birtakım kuşların yuvalarını

${ }^{1}$ Kuş bilimi, kuşları inceleyen zoolojinin alt dalı. 
servi dalları arasına yapmalarından, yılanların bu yuvalardaki yavruları yemeye haris olmalarındandır (Onay 1992: 162).

Bülbülün güle, pervanenin ziyaya karsı temayül beslediği sanıldığı gibi fahtenin de serve mütemayil olduğu, bu cihetle yalnız serve konduğu da farz olunmuştur (Onay 1992: 162).

Tasavvufta servi, görünüşüyle bir (1) sayısını anımsattığından vahdet (birlik) inancı dolayısıyla Tanrı'yı, kumru da boynundaki kuşaktan ve hu çekmesinden dolayı kulu simgeler. Kumrunun, aşkla bağlandığı servinin üzerinden ayrılmadığı anlatılır. Bu hayal, minyatürlerde de kendini gösterir ve servi çizilince mutlaka üstüne bir de kumru eklenir (Eskigün 2006: 80).

\subsection{Karacaoğlan Şiirlerinde ve Bâkî Divanı'nda Kumru}

Türk halk edebiyatının en önemli ozanlarından sayılan Karacaoğlan ve divan şiirinde "Sultanü'ş-şuara" olarak adlandırılan Bâkî'de güzellikler, doğa ve canlılar birbirlerine yakın bir imaj ve hayalle ele alınmıştır.

Karacaoğlan şiirlerinde doğa temalarını çok kullanır. O doğadaki güzellikleri sevgilide, sevgilideki güzellikleri de doğada görür. Ayrıca onun şiirlerinde muhteşem tabiat tasvirleri vardır (Sağlam 2015: 3). Aynı şekilde Bâkî şiirlerinde de doğa ve doğa güzellikleri sıklıkla kullanmıştır. Ancak Bâkî́nin şiirlerindeki doğa kavramı taşra ve kırsal gibi değildir. Onun ele aldığı tabiat daha çok cennet gibi görünen gül ve sevgili bağları ve bahçeleridir. Bâkî́nin sevgilileri de buradaki güllere, servilere ve kuşlara benzemektedir. Çoğunlukla da bu güllerin, servilerin ve kuşların kendileri sevgiliye benzetilmiştir. Kuş türleri de her iki şairin şiirlerinde standardı ve klişeleri aşan bir tasavvurla işlenmiştir.

Karacaoğlan şiirlerinde hümâ gözlü, ispir, balaban ve ceylân bakışlı, kıl ördek boyunlu, tavus kuşu gibi gümüş nakışlı, güvercin duruşlu, keklik sekişli, kumru sesli, arıların balı, kuğu salınışlı sevgililer vardır (Sağlam 2015: 3). Bâkî şiirlerinde ise şahin/doğan gibi kuşlar sevgili gibi avcıdır. Bâkî́nin yüreği ise avdır. Sevgili kuğu ve tavus gibi zarif bir yapıya sahiptir. Bâkî'nin rakipleri ise kara kargalardır.

Çalışma içerisinde Karacaoğlan ve Bâkî şiirlerinde kumru/üveyik kuşunun ele alınış ve işleniş biçimleri incelenecektir. Söz konusu bu kuşun ele alınış özellikleri her iki şairin şiirlerine göre sinıflandırılacaktır. Bu sinıflandırma altında Karacaoğlan'ın dörtlükleri Bâkî'nin de beyitleri ele alınacaktır. Çalışma içerisinde Karacaoğlan'a ait şiirler Saim Sakaoğlu (2004), Cahit Öztelli (1983) ve Müjgân Cunbur'un (2008) yapmış oldukları Karacaoğlan ilgili ilgili çalışmalardan alınmıştır. Bâkî̀ye ait şiirler ise Sabahattin Küçük'ün (1994) çalışmasından elde edilmiştir. Bu çalışmalarda elde edilen verilere göre Karacaoğlan'da kumru/üveyik kuşu dokuz şiirde bulunmaktadır. Bunlardan ikisinde bu kuş üveyik şeklinde yer almaktadır. Bâkî́nin Divan'ında ise bir kaside ve üç gazelde olmak üzere toplam dört şiirde kumru "fâhte" şeklinde karşımıza çıkmaktadır. Bahsi geçen bu şiirlerde kumru kuşu "renk, ses/ötüş, uçuş ve mekân" bağlamlarında incelenecektir.

\subsubsection{Renk}

Kumru veya üveyik kuşu gerçek hayatta gri, kahverengi, boz ve bu tarz renklere yakın bir görünümdedir. Bu şekilde görünmelerinden dolayı yuva yaptıkları yerlere daha rahat uyum sağlamaktadırlar. Karacaoğlan iki şiirinde kumru/üveyik kuşunun renk özelliğine değinmiştir:

Küstürdüm güzeli güldüremedim

Küsme güzellerin şaht isen de

Indiririm güzel seni havadan 
Bir gözleri kanlı üveyk isen de (Sakaoğlu 1994: 404).

Karacaoğlan bu dörtlükte, yoğun bir şekilde kırmızı renkte olan kumrunun/üveyiğin gözlerini ele almıştır. Kumruların göz rengi genel olarak kırmızıdır. İncelenen bu şiirde Karacaoğlan'ın sevgilisinin gözleri, yârinden ayrı düşen kumrunun gözleri gibi kırmızıdır, kanlıdır. Çünkü sevgili, Karacaoğlan'a küsmüştür. Bu metafor ile divan şiirindeki kanlı gözyaşları manzumu benzemektedir.

Beş yüz atım olsa, beş yüz doru

Binse etbâlarm eylese har

Beş yüzü de üveyk, bini de kırı

Beş yüz yedeğine al istersen gönül (Öztelli 1983: 126).

$\mathrm{Bu}$ dörtlükte ve şiirin bütününde zenginliğge kavuşmak isteyen Karacaoğlan hayalindeki atlar ile kumru kuşu arasında bir ilişki kurmuştur. Ona göre atları kumrular gibi çiftler hâlinde durmaktadır ve renkleri de bu kuşlar gibi kahverengi ve kır arasındadır. Karacaoğlan şiirlerinde kumrunun renk bağlamında yer aldığı dörtlükler bunlardır. Bâkî Divanı'nda ise fâhte şeklinde yer alan kumru kuşu renk bağlamında işlenmemiştir.

\title{
2.2.2. Ses/Ötüş
}

Kumru kuşları halk arasında ve edebi ürünlerde daha çok ötüşleri ile bilinmektedir. Baharı, tazeliği, yaşamı ve aşkı çağrıştıran sesleri hem halk hem de divan şiirinde işlenmiştir.

\author{
Kadife şalvarl tül libaslının \\ Güvercin topuklu sarı meslinin \\ Elleri kınalı kumru seslinin \\ Zülüfü gerdana tarayışlının (Sakaoğlu 2004: 528).
}

Karacaoğlan bu dörtlüğünde sevgilisini elleri kınalı bir kumruya benzetmiştir. Kumruların kanatlarının uçları kırmızı veya kına rengindedir. Kınaya benzeyen kanatlarının uçları ile kumru ve gelin olan sevgili arasında bir benzerlik kurulmuştur. Bunun yanı sıra Karacaoğlan'ın gelin sevgilisi kumru kuşu gibi hoş seslidir. Bu hoş sesi ile Karacaoğlan'ı aramaktadır. Karacaoğlan'ın şiirlerine bakıldığında kumru kuşu en çok ses özelliği ile karşımıza çıkmaktadır.

\section{Avlusunda öter kumrular kazlar \\ Çalınır ötede çalgılar sazlar \\ Zülfü top top olmuş gelinler kızlar \\ Bizim de davamız görülsün bugün (Sakaoğlu 2004: 572).}

Bir düğün ortamını betimleyen bu dörtlükte Karacaoğlan, gelinlik çağındaki kızları eşlerini arayan kumrulara benzetir. Tasvir edilen düğün ortamında türküler ve maniler söyleyen gelinlik kızlar ötüşleri ile bilinen kumrulara benzetilmiştir.

\author{
Lale sümbül biter dağın başında \\ Tutu kumru öter dă̆ın peşinde \\ Ulu sular köpük atıp coşanda \\ Geçemem artıyor figanım dağlar (Sakaoğlu 2004: 577).
}

Kumru kuşu Karacaoğlan'ın bu dörtlügüünde ise ötüşüyle bilinen tutu (papağan) ile birlikte ele alınmıştır. Dörtlükte Karacaoğlan dağın peşinde koşan papağan ve kumru gibi feryatlar etmektedir. Tutu ve kumru gibi Karacaoğlan' da yârine kavuşamamaktadır.

Üç kumrudur su başında ötüşür

Yol üstünde bana seyran yetişir

Korkut Ata Türkiyat Araştırmaları Dergisi
Uluslararası Türk Dili ve Edebiyatı Araştırmaları Dergisi
The Journal of International Turkish Language \& Literature Research
Sayı 5/ Ağustos 2021


Yatışır mı deli gönül yatışır

Avcıyım amm'anlar benden şahandır (Sakaoğlu 2004: 600).

Bu dörtlükte üç kumrunun su başında ötüştüğü görülmektedir. Ötüş, sayı ve mekân bağlamlarının birlikte ele alındığı bu dörtlükte de kumrular eşlerini aramaktadırlar. Şiirin bütününe baktığımız zaman Karacaoğlan üç tane güzele tutulmuştur.

Bülbülüm, kekliğim öter kafesten

Dudu kumrumu aldırdım destten

Yüzükler yaptırmış kaşı elmastan

Kınahı parmaklar el ele karşı (Öztelli 1983: 413).

Karacaoğlan bu dörtlükte başkası ile evlenmek üzere olan sevgisine seslenmektedir. Sevgilisi evlenerek altın bir kafese konmuş ve orada papağan gibi ötmektedir ve Karacaoğlan bu durumdan yakınmaktadır.

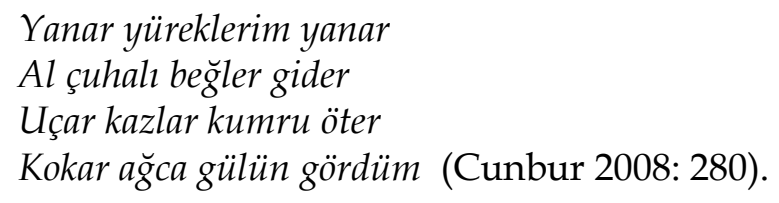

Genel olarak Karacaoğlan kumru/üveyik kuşunu ses bağlamı üzerinden şiirlerinde işlemiştir. Kumru kuşunun yer aldığı dokuz şiiri olmasına rağmen altı şiiri ses ve ötüş üzerine kuruludur. Bâkî Divanı'na bakacak olursak bu konuda bir ortaklık görebiliriz. Kumru/fâhte Bâkî Divanı'nda seherde uyanık olmasıyla ve ötmesiyle anılmıştır. Kumru bu özellikleri ile divan şiirinde bülbüle benzemektedir.

Çemen etfâlinüñ uyhuların uçurdı yine

Subh-dem gulgule-i fâhte gül-bâng-i hezâr ${ }^{2}$ (Küçük 1994: 30).

"Sabah vakti üveyik kuşunun ötüşü ve bülbülün şakıması çimen çocuklarının yine uykularını kaçırdı."

Fâhte/üveyik erken uyanıp seherde öten kuşlardandır. Üveyik bu ötüşü ve bülbülün gülbangi, gül bahçesinin çocukları olan çiçeklerin ve fidanların uykusunu kaçırmaktadır. Ayrıca Bâkî’nin bu şiirine göre üveyik de tıpkı bülbül gibi âşıklara benzetilir. Bu iki âşık her sabah sevgililerine kavuşmak için ötüşür.

Mürg-i dil-i Bâkîyi görün fâhteâsâ

Efgân ider ol serv-i hırâmânuñ ucından³ (Küçük 1994: 231).

“Bâkî̀nin gönül kuşuna bakın! Üveyik kuşu gibi, salınan servi boylu sevgili yüzünden feryat etmektedir."

Bâkî de üveyik kuşu gibi uzun, servi boylu bir güzele âşıktır ve bundan dolayı üveyik feryat etmektedir. Bu bakımdan divan şiirinde üveyik kuşu bülbül gibi dertlidir. Üveyiğe benzeyen şair de aşk ateşi ile yanmaktadır.

Bâkî nice bir fâhteveş bâg-ı belâda

Nâlân olam ol serv-i hırâmânuñ elinden ${ }^{4}$ (Küçük 1994: 233).

“Bâkî, belâ bağında nice bir üveyik kuşu gibidir. O servi boylunun elinden nâlân olayım."

2 Bâkî, K. 18/10.

3 Bâkî, G. 356/5.

4 Bâkî, G. 359/7. 
Bâkî, üveyik kuşu gibi gerçek aşkın yokluğunda ötmektedir. Bu yüzden servi boylu güzelin elinden inlemek istemektedir.

Subh-dem ey fâhte bîhûde efgân eyleme

Çün girürsin her gice bir serv-i bâlâ koynına 5 (Küçük 1994: 264).

"Ey üveyik! Madem her gece bir uzun boylu servinin koynuna giriyorsun, o zaman her sabah boştan yere feryat etme."

Bâkî her ne kadar üveyik kuşuna benzese de üveyik kuşu her gece bir servinin koynuna girer ama kendisi sevgilisine kavuşamaz. Bundan dolayı üveyik kuşunun dert yanmasını saçma bulur. Bâkî bu açıdan üveyikten daha dertlidir ve asıl feryat etmesi gereken odur.

Genel olarak Bâkî Divanı'nda kumrunun yer aldığı beyitler bunlarla sinırlıdır. Karacaoğlan'ın şiirlerinde sevgili kumru kuşuna benzeyip kumru kulu gibi öterken Bâkî şiirlerinde sevgili servidir kumru ise âşıktır. Ayrıca Karacaoğlan şiirlerinde kumru-servi ilişkisine hiç değinilmemiştir. Bâkî şiirlerinde ise bu mazmun sürekli yer almaktadır. Karacaoğlan'da kumru güzelliği ve sevgilinin sesini simgelerken Bâkî’de acıyı ve feryat etmeyi simgelemektedir.

\subsubsection{Uçma/Uçuş}

Çalışma içerisinde incelenen konu bir kuş türü olduğu için uçma/uçuş eylemi ve özelliği incelenmesi gereken unsurlar arasında yer almalıdır. Ancak kumrunun uçma özelliği Karacaoğlan'ın sadece bir şiirinde yer alırken Bâkî Divanı'nda kumrunun uçma özelliğine hiç değinilmemiştir.

Yandı Çukurova yandı

Eli bazlı beğler indi

Tutu uçtu kumru kondu

Akça Deniz gölün gördüm (Sakaoğlu 2004: 513).

$\mathrm{Bu}$ dörtlükte Karacaoğlan'ın tutuya ve kumruya benzettiği sevgilileri bulunmaktadır. Tutu sevgili uçup gittiğinde kumru sevgilisi uçup gelir. Ayrıca burada bir av tasviri de bulunmaktadır. Şahin ile avlanan beyler tutuları oldukları yerden havalandırmıştır. Kumrular ise havada şahinler tarafından yakalanacaklarını bildikleri için yere inmişlerdir.

\subsubsection{Mekân}

Kumru kuşunu mekân bağlamında ele alacak olursak Karacaoğlan şiirlerinde kumru daha kırsal bölgelerde bulunmaktadır. Bâkî şiirlerde ise kumru bahçelerde ve servi ağaçlarında yaşamaktadır.

\section{Avlusunda öter kumrular kazlar \\ Çalınır ötede çalgılar sazlar \\ Zülfü top top olmuş gelinler kızlar \\ Bizim de davamız görülsün bugün (Sakaoğlu 2004: 572).}

Ses/ötüş bağlamında daha önce ele alınan bu dörtlükte Karacaoğlan'ın sevgilisinin avlusunda kumruların öttüğünü görmekteyiz. Günlük yaşamda da kumruların bahçelerde, üstü açık avlularda ve sokaklarda dolaştıklarını görebiliriz. Bunun yanı sıra sevgilinin avlusunda kumrunun bulunması ile divan şiirindeki sevgilinin bahçesinde kumrunun ötmesi arasında bir benzerlik bulunmaktadır.

5 Bâkî, G. 430/2. 
Lale sümbül biter dă̆ın başında

Tutu kumru öter dağın peşinde

Ulu sular köpük atıp coşanda

Geçemem artıyor figanım dağlar (Sakaoğlu 2004: 577).

$\mathrm{Bu}$ dörtlükte ise kumru kuşunu dağın etrafında döndüğünü görmekteyiz. Dağ, tepe ve mağaralar kumruların yaşadıkları yerler arasındadır.

Üç kumrudur su başında ötüşür

Yol üstünde bana seyran yetişir

Yatışır mı deli gönül yatışır

Avcıyım amm'anlar benden şahandır (Sakaoğlu 2004: 600).

Karacaoğlan'ın bu şiirinde genelde tek olarak ve dağda ve avluda gördüğümüz kumru kuşu bu dörtlükte üç tane olarak su başında ötüşmektedir.

Çemen etfâlinü̈̃̃ uyhuların uçurdı yine

Subh-dem gulgule-i fâhte gül-bâng-i hezâr6 (Küçük 1994: 30).

"Sabah vakti üveyik kuşunun ötüşü ve bülbülün şakıması çimen çocuklarının yine uykularını kaçırdı."

Subh-dem ey fâhte bîhûde efgân eyleme

Çün girürsin her gice bir serv-i bâlâ koynına7 (Küçük 1994: 264).

"Ey üveyik! Madem her gece bir uzun boylu servinin koynuna giriyorsun, o zaman her sabah boştan yere feryat etme."

Bâkî Divan'ına bakacak olursak daha önce incelenen bu iki beyitte üveyiğin bir bahçede ve servi ağaçlarında yaşadığını veya durduğunu söyleyebiliriz. Servi ağacı divan şiirine göre üveyiğin sevgilisidir. Ancak halk şiirinde kumru-üveyik ilişkisini görmemekteyiz.

\section{Sonuç}

Türk halk edebiyatı ve divan edebiyatı arasında pek çok benzerlik ve müştereklik bulunmaktadır. Bu çalışma içerisinde yapılan “Karacaoğlan şiirlerinde ve Bâkî Divanı'nda kumru kuşu" incelemesi de divan ve halk edebiyatının benzer ve aynı konuları, motifleri ve mazmunları işlediğini göstermektedir.

İncelenen iki şairde de kumru/üveyik motifine ve kullanımına rastlanmıştır. Kumru kuşu Karacaoğlan şiirlerinde dokuz defa kullanılmıştır. Bâkî şiirlerinde ise "fâhte" şeklinde bir kaside ve üç gazelde yer almaktadır. Hem Karacaoğlan hem de Bâkî şiirlerinde kumru/üveyik "ses ve mekân" bağlamında yer almaktadır. "Renk ve uçuş" bağlamında ise Karacaoğlan'da kumru/üveyik işlenmiştir. Bâkî şiirlerinde ise bu bağlamlar ele alınmamıştır.

Doğal ortamında eşler hâlinde yaşayan kumru/üveyik kuşu her iki şairin şiirlerinde ise tek yönlü âşık/sevgili olarak karşımıza çıkmaktadır. Karacaoğlan'ın şiirlerinde güzel sevgililer kumru/üveyik kuşuna benzemektedirler. Karacaoğlan'ın sevdiği güzeller ve gelinler kumru seslidirler ve ellerinin kınalı olmasından dolayı kumrulara benzemektedirler. Bâkî şiirlerine bakıldığında ise Karacaoğlan' daki kumru ele alınışın tam tersi görülmektedir. Bâkî şiirlerinde üveyik kuşu âşığa benzemektedir. Âşık, sevgilisi için feryat ederken üveyik de servi için feryat figan etmektedir. Bunların yanı sıra

6 Bâkî, K. 18/10.

7 Bâkî, G. 430/2.

Korkut Ata Türkiyat Araştırmaları Dergisi
Uluslararası Türk Dili ve Edebiyatı Araştırmaları Dergisi
The Journal of International Turkish Language \& Literature Research
Sayı 5/Ağustos 2021


Bâkî şiirlerinde üveyik kuşu sevgilinin bahçesinde ve servi ağaçlarında yaşamaktadır. Karacaoğlan şiirlerinde yer alan kumrular ise Karacaoğlan gibi dağlarda, su kenarlarında ve bazen de sevgilinin avlusunda bulunmaktadır.

Sonuç olarak iki şair arasında konu müşterekliği bulunmaktadır. Ele alınan bağlamlar bu iki şair arasında fazla benzerlik göstermemektedir. Ancak başka bir halk ozanı ile bir başka divan şairi arasında, çalışma içerisinde incelenen bu bağlamlar daha fazla ortaklık ve benzerlik içerebilir.

\section{Kaynakça}

Ceylan, Ömür (2007). Kuşlar Dîvânı: Osmanlı Şiir Kuşları. İstanbul: Kapı Yayınları.

Cunbur, Müjgân (2008). Karacaoğlan: Koşmalar, Varsağılar, Semâîler, Destanlar, Türküler. İstanbul: Çağrı Yayınları.

Çavuşoğlu, Mehmed (1986). Divan Şiiri. Türk Dili, 415-417, 52, 1-16.

Çelebioğlu, Âmil (1998). Eski Türk Edebiyatı Araştırmaları. İstanbul: MEB Yayınları.

Devellioğlu, Ferit (2006). Osmanlıca-Türkçe Ansiklopedik Lîgat. Ankara: Aydın Kitabevi Yayınları.

Eskigün, Kübra (2006). Klasik Türk Şiirinde Efsanevi Kuşlar. Kahramanmaraş: Kahramanmaraş Sütçü İmam Üniversitesi SBE Yayımlanmamış Yüksek Lisans Tezi.

Köprülü, Mehmet Fuad (1980). Türk Edebiyatı Tarihi. İstanbul: Ötüken Yayınları.

Kurnaz, Cemal (2011). Halk Şiiri ve Divan Şiirinin Müşterekleri. Ankara: Berikan Yayınevi.

Küçük, Sabahattin (1994). Bâkî Divanı. Ankara: TDK Yayınları.

Onay, Ahmet Talât (1992). Eski Türk Edebiyatında Mazmunlar ve İzahı. (Hzl. Cemal Kurnaz). Ankara: TDV Yayınları.

Öztelli, Cahit (1983). Karaca Oğlan, Yaşamı ve Bütün Şiirleri. Ankara: Özgür Yayın Dağıtım.

Sağlam, Ferhat (2015). Karaca Oğlan'ın Şiirlerinde Hayvan İsimleri. Zeitsschrift für die Welt der Türken Journal of World of Turks, 2(7), 315-335.

Sakaoğlu, Saim (2004). Karaca Oğlan. Ankara: Akçağ Yayınları.

Yağbasan, Mehmet Zeki (1992). Halk Edebiyatı-Divan Edebiyatı Etkileşimleri. İstanbul: İstanbul Teknik Üniversitesi SBE Yayımlanmamış Yüksek Lisans Tezi. 